\title{
Application of Educational Games for Formation and Development of ICT Competence of Teachers
}

\author{
https://doi.org/10.3991/ijet.v14i15.10572 \\ Anatoliy S. Petelin (四) \\ Voronezh State Pedagogical University, Voronezh, Russia \\ anatoliy.s.petelin@gmail.com \\ Olga V. Galustyan \\ Southern Federal University, Rostov-on-Don, Russia \\ Tatyana S. Prosvetova \\ The Military Educational and Scientific Center of "The Air Force Academy named after \\ Zhukovsky N.E. and Gagarin Y.A.”, Voronezh, Russia \\ Elena A. Petelina, Alexander Yu. Ryzhenkov \\ Voronezh State Pedagogical University, Voronezh, Russia
}

\begin{abstract}
The process of developing ICT competence of teacher is not only related to fundamental theoretical knowledge, but also to a wide range of practical professional skills. One of the important means of developing ICT competence of teachers are educational games within the course of their professional development. Educational game is a reproduction of real professional situations. It allows participants to experiment, to develop various actions, to make and to correct mistakes which are unacceptable in real life. The experience of educational games within the course of ICT competence development showed that there is a more intensive exchange of ideas and information, which encourages participants to the creative process.
\end{abstract}

Keywords-Development, ICT competence, personal, professional, qualities, game, teacher

\section{Introduction}

Modern pedagogical issues [1, 8-11] related to the means of forming and developing professionally important qualities of specialists in the process of professional training are being developed nowadays. It is important to mention that special place belongs to educational games among them. Authors $[3,5,15,17]$ consider that educational games fully contribute to the solution of the task of forming professionally important qualities of future specialists among the variety of gaming methods and techniques. Using of educational games is precisely important because it allows its participants to reveal themselves, to take an active position, to improve their professionalism. Moreover, educational games are one of the active forms of organizing the 
courses of the development of ICT competence of teachers as they provide an increase of pedagogical competence level of the teachers [19].

Researches $[4,7,12]$ has devoted their studies to various aspects of using of games in teaching. The role of using games in vocational training is great. It is a unique mechanism for the transferring of social experience, which is associated with certain rules and norms of behavior in various situations. Games as a method of learning allow increasing of motivation for studying any discipline, transferring specialist from the passive state to the active one. Game can be considered as a way of obtaining the initial experience, as well as the formation of pluralism of opinions, the multivariance of thought operations, increasing interest in future professional activity.

Organizational and activity games within the course of the development of ICT competence of teachers are of a particular importance [13, 16, 18]. It is a form of collective thought activity, in the process of which specialists master their methodological culture as they develop their own vision of the problem and find possible ways of solving them. This game method for analyzing and solving complex problems don't have a unique solution.

\section{$2 \quad$ Methodology}

$[3,14,20]$ consider that educational games have always been as an effective form of training. They are used to try oneself in specially created game situations. Games are of interest to people of any age. Practical solution, analysis and development of the most effective behavior patterns in the proposed circumstances will help the teachers to avoid many mistakes, to acquire the initial experience of communication and activity.

$[2,4,7]$ reveal in their scientific works that games are defined as a method for simulating various situations of professional activity by playing them out according to the certain rules. Educational games enable participants to practice production situations, and thereby acquire a primary professional experience. Activity of organization, school, enterprise can be recreated, a business meeting can be simulated, a work plan can be simulated, a lesson, a conversation with the student or client can be held during the game. Educational games have a specific purpose, tasks, a description of roles, and a plot. Methods of behavior, tactics of action, and the performance of duties of a specific specialist can be practiced within the game. Educational games are carried out on certain stages and includes the stages of preparation, conduct and analysis.

Educational game is a process in which participants are invited to play another person or to play a certain problem situation. This is an effective development of behavioral options in situations in which teachers may find themselves in the period of practice, in future professional activity (for example, conflicts with colleagues, job interviews, etc.). The role is assumed at the cognitive, emotional and behavioral levels and manifested through the appropriation of external features and norms of behavior. A sign that distinguishes educational games from other educational activities is the absence of an evaluation system within the course of the game. It is not interrupted for discussion. All this provides a certain naturalness and maximum immersion of partic- 
ipants within the game process. The emotional effect of the educational games is built on the participants' "living" in new experiences in the game environment, on the "discoveries" that a person makes while participating are in the game $[6,20]$.

\section{$3 \quad$ Materials and Methods}

Experimental work took place in 2017-2018 at universities (Southern Federal University, Institute of Social Education) of Rostov-on-Don and Voronezh within the training courses on the development of ICT competence. 158 teachers participated in the study. Respondents were from 35 to 50 years of age. The experimental group consisted of 79 teachers. The content part of the experiment was represented by the course "Teachers' Activity in Creating Electronic Educational Environment". The control group included 78 teachers. They were trained in the traditional face-to-face education without using educational games in the classroom. The experimental group was trained on the course using educational games.

Educational games were conducted by the specialists on the basis of deep theoretical study of the problems. Ideally, the game lasted several days and included such three stages as preparatory, playful and reflexive one.

Educational games were used within the educational process. The duration of such games was 6-8 hours. The game players were teachers who had experienced the participation in such games. The main goals of such games are the following:

- The formation of a professional orientation among the participants and increasing their interest in their professional activities

- Development of the ability to professional self-determination and reflection

- Integration of existing diverse knowledge of the participants within the game and teaching them how to use them in practical professional activities

- The opportunity to disclose the creative potential of each participant

We consider that participants should not only acquire knowledge, but also develop their skills within the educational process. At the same time, professional training should not only provide specialization in one of the areas of training, but also provide with the opportunity to carry out expert evaluation and design of various educational systems.

The goal of educational games is to assimilate the meaning of complex texts or problems. Participants are given their roles which they perform in advance. Role is a certain point of view, an attitude that presupposes some way of its manifestation. The main structural element of educational games is the predetermined opposition of positions that are in relation to the same content. The participants of educational games had an opportunity to analyze their own content and logical positions through comparison and even confrontation with other positions and opinions.

Participants were divided into subgroups of four to six people each one. Then each group was given a piece of paper, which indicated the position with which they would analyze the proposed content during the game. Each position was a definite way of 
structuring the scientific content (a lecture, an article, a monograph, etc.). These positions were universal, but others could be designed for each specific material.

The following positions were used to which exemplary instructions were suggested (specific formulations depend on the actual group of students and their experience in participating in games):

- Thesis: Participants were to select several theses from the text of the lecture. Thesis meant some clearly formulated, completed thought, a statement that required proof.

- The concept: Participants were to select several concepts and to disclose their content from the content of the text.

- Scheme: Participants were to reflect the content of the text in the form of a diagram. The scheme should reflect the most significant relationships between concepts. It was desirable to use words as little as possible in the scheme, but to use other means (different kinds symbols, etc.).

- Proof: Participants were to become adepts of the contents of the presented text. It was necessary to invent and write down on the leaflet several provisions that seemed the most attractive. It was necessary to put forward a system of evidence and justification to each thesis. Evidences could be examples from life, mental experiments, etc.

- Opposition: Participants were to follow the instructions opposite to the previous ones. That meant that participants were to highlight several provisions and to prove their falsity. The methods of refutation could be arbitrary. Participants shouldn't forget that all positions were conditional. That meant that participants might agree with everything in real life.

- Association: Participants were to build an associative series in relation to the content of the text. Associations could be of any type (drawing or a phrase from a movie, etc.). It was important to indicate to which of the content elements each proposed association belonged to a participant (for example, content, fragment, phrase, thesis, position).

- Poetry: Participants were to reflect the content of the text in a poetic form. They were to reveal what they considered the most important thing in verse.

- Question: Participants were to come up with two or three questions for each group. They could guess concerning the content that would be presented during the group's performance, but they didn't know from what position they would analyze the material.

Participants were given time to get prepared after giving instructions. The main task of the instructor, who conducted educational game was to ensure a profound assimilation of the content of the text, to construct a new vision of the situation within discussion. 


\section{$4 \quad$ Results}

Initial study was conducted to identify the initial level of ICT competency in the experimental and control groups at the beginning of courses. We have identified project, strategic, organizational, creative components within the structure of ICT competence. Project component is an integrative characteristic of the person, which is expressed in the ability and readiness of a person for independent theoretical and practical work on the development and implementation of projects in various fields. Strategic component is willingness and ability of the person, which is expressed in planning actions to achieve certain result, planning a flexible activity program or an algorithm for planning certain actions, a sequence of rules, and strict prescriptions for overcoming difficulties. Organizational component is not only organizational skills related to the organization of different events, skills of time management and decision making. Creative component includes creative abilities of the individual, characterized by readiness for spawning fundamentally new unusual ideas deviating from traditional or accepted patterns of thinking, as well as the ability to solve problems arising in the process of activity. The data obtained were summarized and converted to percentage. The empirical data were quantitatively processed and analyzed at a qualitative level. Dynamics of step-by-step development of ICT competence was established and the obtained data are revealed in Table 1 and Table 2.

Table 1. The results of the assessment of the level of ICT competence in the experimental and control groups before the experimental work

\begin{tabular}{|l|c|c|c|c|c|c|}
\hline \multirow{2}{*}{\multicolumn{1}{c}{$\begin{array}{c}\text { ICT } \\
\text { Competence }\end{array}$}} & \multicolumn{3}{c|}{ Experimental group } & \multicolumn{3}{c|}{ Control group } \\
\cline { 2 - 7 } & $\begin{array}{c}\text { Low level, } \\
\text { \% }\end{array}$ & $\begin{array}{c}\text { Middle } \\
\text { level, \% }\end{array}$ & $\begin{array}{c}\text { High level, } \\
\text { \% }\end{array}$ & $\begin{array}{c}\text { Low level, } \\
\text { \% }\end{array}$ & $\begin{array}{c}\text { Middle } \\
\text { level, \% }\end{array}$ & $\begin{array}{c}\text { High level, } \\
\text { \% }\end{array}$ \\
\hline Project component & 41,9 & 38,9 & 19,2 & 40,3 & 39,5 & 20,2 \\
\hline Strategic component & 56,6 & 28,5 & 14,9 & 37,6 & 40,5 & 21,9 \\
\hline Organizational component & 43,2 & 33,3 & 23,5 & 42,7 & 29,8 & 27,5 \\
\hline Creative component & 57,8 & 29,3 & 12,9 & 43,7 & 35,4 & 20,9 \\
\hline
\end{tabular}

Table 2. The results of the assessment of the level of ICT competence in the experimental and control groups after the experimental work

\begin{tabular}{|c|c|c|c|c|c|c|}
\hline \multirow{2}{*}{$\begin{array}{c}\text { ICT } \\
\text { competence }\end{array}$} & \multicolumn{3}{|c|}{ Experimental group } & \multicolumn{3}{|c|}{ Control group } \\
\hline & $\begin{array}{c}\text { Low level, } \\
\%\end{array}$ & $\begin{array}{l}\text { Middle } \\
\text { level, \% }\end{array}$ & $\begin{array}{c}\text { High level, } \\
\%\end{array}$ & $\begin{array}{c}\text { Low level, } \\
\%\end{array}$ & $\begin{array}{l}\text { Middle } \\
\text { level, \% }\end{array}$ & $\begin{array}{c}\text { High level, } \\
\%\end{array}$ \\
\hline Project component & 12,1 & 38,5 & 49,4 & 42,8 & 39,4 & 17,8 \\
\hline Strategic component & 7,3 & 27,2 & 65,5 & 35,3 & 43,9 & 20,8 \\
\hline Organizational component & 7,8 & 24,1 & 68,1 & 33,7 & 39,4 & 26,9 \\
\hline Creative component & 4,7 & 28,6 & 66,7 & 42,1 & 37,8 & 20,1 \\
\hline
\end{tabular}

Comparative analysis of the results of input and final diagnostics of the formation of ICT competence of teachers in the control and experimental groups showed a significant dynamic of the development of ICT competence in experimental groups, which indicates the effectiveness of the experimental work. 


\section{Discussion}

Educational games can be used as in the process of theoretical training and as a method of the formation of ICT competence of teachers.

[21] considered that games had been already become widespread as means and method for solving complex interdisciplinary, inter professional and even intercultural problems which are of major economic importance. Moreover, games can be used as a convenient and sufficiently effective form of formation and developing of ICT competence of teachers, and, therefore, they can be discussed as a new social and cultural phenomenon of modern life. Game arises as a way of understanding methodology. According to [21] methodology is not just a doctrine of means and methods of our thinking and our activity, but an absolute special form of organization of thinking activity and people's activities. Methodology cannot be transferred as knowledge or a set of tools from one person to another, but it can be grown in a new sphere of methodological thinking thought activity and provide people with a complete and integral life activity. Game is a sphere of thinking activity.

Educational games differ in their features and goals, as the unique tools are used to achieve them. Therefore, the format and methodology of educational games depends on what kind of skills you need to develop, what tasks it is necessary to learn in order to solve the problems to obtain new skills.

The advantages of teaching opportunities of educational games as an active learning method comparing to the traditional methods are that the goals of the game are more consistent with the practical needs of participants. This form of organization of the educational process removes the contradiction between the abstract nature of the professional discipline and the real nature of the professional activity.

We formulated the following advantages and disadvantages of educational games in the formation of ICT competence of teachers:

- Educational games can significantly reduce the time of accumulation of ICT competence.

- Educational games provide an opportunity to experiment with an event, try different strategies for solving problems.

- There is real process, but not abstract for the participants, the dynamics of the development of the educational game plot, the formation of a holistic image of the professional situation.

- Educational games allow the future specialists to form a holistic view.

- Educational games allow the participants to gain social experience (communication, decision making, etc.).

Advantages of educational games determine the success of the application of this method in the educational process.

However, it is necessary to note some drawbacks that can reduce the attractiveness of using this approach in some educational programs: 
- Educational game is quite a laborious and resource-intensive form of training. Therefore, the result obtained may not always justify the funds spent on the organization of the process.

- It is impossible to conduct educational game on the topic which the participants have no idea about. This means that competent participation in the game is possible only if they have the relevant knowledge or prior training.

Thus, it makes sense to use educational games when it is important:

- To develop of existing skills of the participants in the implementation of their professional activities.

- To get an experience working in a team.

- To form professional creative thinking.

\section{Conclusion}

As various forms and mechanisms for formation and development of ICT competence of teachers are possible, but the most effective one is educational game. Ideally it should be initiated by the teachers themselves, with the primary support of the educator. Using games as an educational tool provides opportunities not only for deeper learning, but also for further development of ICT competence of teachers.

We define the mechanisms formation and development of ICT competence of teachers within the educational games such as:

- Direct involvement of each participant into the educational game due to the extensive structure of its organization

- Consideration of opinions and protection of interests of each participant

Thus, this article presents the means for formation and development of ICT competence of teachers, which provide the opportunity to design and to implement individual trajectories of their professional development.

\section{$7 \quad$ References}

[1] BUETTNER, C. K., JEON, L., HUR, E., \& GARCIA, R. E. (2016). Teachers' SocialEmotional capacity: Factors associated with teachers' responsiveness and professional commitment. Early Education and Development, 27(7), https://doi.org/10.1080/1040 9289.2016.1168227

[2] CAMPBELL, L. (2018). Pedagogical bricolage and teacher agency: Towards a culture of creative professionalism. Educational Philosophy and Theory, 1-10. https://oi.org/10. $\underline{1080 / 00131857.2018 .1425992}$

[3] COBELLO, S., BERGANZA, P. P., MILLI, E., ZYGOURITSAS, N. (2017). The value of establishing a community of teachers for the gamification of prosocial learning: Pegadogical, social and developmental aspects of a teachers' community space experience. Paper presented at the 2017 9th International Conference on Virtual Worlds and Games for 
Serious Applications, VS-Games 2017 - Proceedings, 189-192. https://doi.org/10.1109/vsgames.2017.8056600

[4] CUI, X., ZHANG, Z., \& SUN, L. (2017). Research and implementation of role-playing teaching mode supported by gamification. Journal of Physics: Conference Series, https://doi.org/10.1088/1742-6596/887/1/012054

[5] DE DIOS ALIJA, T., RAMOS, J. M. G., \& PÉREZ, S. M. (2017). Design of a model of teacher evaluation and development in a private university. [Diseño de un modelo de evaluación y desarrollo docente en una universidad privada] Revista Complutense De Educacion, 28(1), 61-80. https://doi.org/10.5209/rev rced.2017.v28.n1.48718

[6] DOLEV, N., \& LESHEM, S. (2017). Developing emotional intelligence competence among teachers. Teacher Development, 21(1), 21-39. https://doi.org/10.1080/13664530. $\underline{2016.1207093}$

[7] FUGLSETH, A. M., GRØNHAUG, K., JÖRNSTEN, K. (2018). Students' ability to apply their knowledge in a gaming exercise: An exploratory study. Scandinavian Journal of Educational Research, 62(1), 88-108. https://doi.org/10.1080/00313831.2016.1212255

[8] GALUSTYAN, O. V. (2015). Digital Campus as Electronic Image of the University. Rupkatha Journal on Interdisciplinary Studies in Humanities, 7(3). Retrieved from http:// rupkatha.com $/ \mathrm{V} 7 / \mathrm{n} 3 / 28$ digital-campus.pdf

[9] GALUSTYAN, O.V. BEREZHNAYA, I.F., BELOSHITSKY, A.V. (2017). Professional and Career Development of Teachers. Sodobna Pedagogika / Journal of Contemporary Educational Studies, 68(№4), 158-172. Retrieved from http://www.sodobna-pedagogika. net/wp-content/uploads/2017/12/8-galustyan ang-2017-4.pdf. https://doi.org/10.18411/a$\underline{2017-023}$

[10] Galustyan, O. V., Lazukin, V. F., Petelin, A. S., Ostapenko, V. S. (2018). Diagnostic Activity of Teachers at High School. Revista Espacios, Vol. 39(N 10). Retrieved from http http://www.revistaespacios.com/a18v39n10/18391024.html

[11] GALUSTYAN, O.V. (2017). Some Methodological Aspects of the Evaluation of Students' Educational Achievements at University. (IJCRSEE) International Journal of Cognitive Research in Science, Engineering and Education, 5(1), 43-48. Retrieved from http://www.ijcrsee.com/index.php/IJCRSEE/article/view/7/9. https://doi.org/10.5937/ijcrse e1701043g

[12] GLADILINA, I. P. (2016). Creativity in the structure of professionalism of a higher school teacher. International Journal of Environmental and Science Education, 11(8), 1691-1699.

[13] HUMBURG, L. (2017). The changing teaching personality: From expert on techniques to designer of holistic learning. [Die Lehrerpersönlichkeit im Wandel der Zeit: Vom Experten für Techniken zum Gestalter ganzheitlichen Lernens] Manuelle Medizin, 55(6), 360-363. https://doi.org/10.1007/s00337-017-0322-0

[14] KAO, G. Y., CHIANG, C., SUN, C. (2017). Customizing scaffolds for game-based learning in physics: Impacts on knowledge acquisition and game design creativity. Computers and Education, 113, 294-312. https://doi.org/10.1016/j.compedu.2017.05.022

[15] KOMAROVA, E.P., FETISOV, A. S., LARINA, T.V., GALUSTYAN, O.V. (2017). The Development of Physical Training Culture of a Personality. Revista Espacios, Vol. 38(N 50). Retrieved from http://www.revistaespacios.com/a17v38n50/17385028.html

[16] KOWALCZUK-WALĘDZIAK, M., LOPES, A., MENEZES, I., \& TORMENTA, N. (2017). Teachers pursuing a doctoral degree: Motivations and perceived impact. Educational Research, 59(3), 335-352. https://doi.org/10.1080/00131881.2017.1345287

[17] KRAVCHENKO E.V., GALUSTYAN O.V, KOVTUNENKO L.V., KOLOSOVA L.A. (2018). Pedagogical Practice of Students. Revista Espacios, Vol. 39(N 17). Retrieved from http://www.revistaespacios.com/a18v39n17/18391731.html 
[18] KULIKOVA, T. I., \& MALIY, D. V. (2017). Professional and personal qualities of the teacher in the context of the psychological safety of educational environment. European Journal of Contemporary Education, 6(4), 715-722. https://doi.org/10.13187/ejced.2017. 4.715

[19] PONTUAL FALCÃO, T., MENDES DE ANDRADE E PERES, F., SALES DE MORAIS, D.C., DA SILVA OLIVEIRA, G. (2018). Participatory methodologies to promote student engagement in the development of educational digital games. Computers and Education, 116, pp. 161-175. https://doi.org/10.1016/j.compedu.2017.09.006

[20] SÁNCHEZ-MARTÍN, J., CAÑADA-CAÑADA, F., \& DÁVILA-ACEDO, M. A. (2017). Just a game? Gamifying a general science class at university: Collaborative and competitive work implications. Thinking Skills and Creativity, 26, 51-59. https://doi.org/ 10.1016/j.tsc.2017.05.003

[21] SCHEDROVITSKY, G. P., KOTELNIKOV, S. I. (1983). Educational and Business Games as New Form of Organization and Method of Collective Thinking Activity. Innovations in Organizations, 43. (in Russian). Retrieved from http://www.fondgp.ru/lib/ collections/archive/online/83c

\section{Authors}

Anatoliy S. Petelin is Professor of Department of Theory and History of Music and Musical Instruments of Voronezh State Pedagogical University, Voronezh, Russia.

Olga V. Galustyan is Professor of the Department of Education and Pedagogical Sciences of Southern Federal University, Rostov-on-Don, Russia.

Tatyana S. Prosvetova is Professor of Department of Moral and Psychological Support of The Military Educational and Scientific Center of "The Air Force Academy named after Zhukovsky N.E. and Gagarin Y.A.”, Voronezh, Russia.

Elena A. Petelina is Associate Professor of Department of Theory and History of Music and Musical Instruments of Voronezh State Pedagogical University, Voronezh, Russia.

Alexander Yu. Ryzhenkov is Professor of Department of Theory and History of Music and Musical Instruments of Voronezh State Pedagogical University, Voronezh, Russia.

Article submitted 2019-03-30. Resubmitted 2019-05-15. Final acceptance 2019-05-28. Final version published as submitted by the authors. 